\title{
流れの水深積分モデルと非平衡流砂モデル による反砂堆不安定性
}

\author{
井上 卓也 1 ・岩崎 理樹 2 音田 慎一郎3 \\ 1正会員 博 (工) 研究員 (国研) 土木研究所 寒地土木研究所 ( T062-8602 札幌市豊平区平岸1-3-1-34) \\ E-mail:inoue-t@ceri.go.jp \\ 2 正会員 博 (工) 研究員 (国研) 土木研究所 寒地土木研究所 ( \\ E-mail: iwasaki-t@ceri.go.jp \\ 3 正会員 博 (工) 京都大学大学院助教工学研究科都市社会工学専攻 ( \\ E-mail: onda.shinichiro.2e@kyoto-u.ac.jp
}

流れの抵抗に影響を及ぼす小規模河床波の発生・発達は，河川工学分野における重要テーマの一つであ る. 本研究では, ブシネスク方程式と非平衡流砂モデルを組み合わせたモデルに対して線形安定解析を行 った. また浅水流方程式や平衡流砂モデルを用いた場合の分析も行い，ブシネスク項や流砂の非平衡性が 河床波の不安定性と波長へ与える影響を考察した。この結果，ブシネスク方程式のみ，もしくは非平衡流 砂モデルのみでは，反砂堆の不安定性を表現できないが，2つを組み合わせることにより，既往の反砂堆 実験結果と良好な整合性が得らることが確認された。

Key Words : antidunes, linear stability analysis, Boussinesq equation, non-equilibrium sediment transport

\section{1. はじめに}

急流河川では出水時に部分的に反砂堆が発生し，それ により水面が恐竜の背びれのように盛り上がる現象がし ばしば観測される（写真-1）。この水面波は時に $2 \mathrm{~m} \sim$ 3m の巨大な波に発達寸るため, 橋桁への衝突などが危 惧されている. また, 反砂堆や砂堆などの小規模河床波 の発達・遷移は, 流れの抵抗に影響を及ぼすことから, 河川工学分野において重要なテーマである.

上述のような小規模河床波の発生機構を説明するため に，これまでに数多くのモデルが提案されている．例え ば，Kennedy ${ }^{1) や ~ H a y a s h i ' ~}{ }^{2}$ はポテンシャル流解析に局所流 速と流砂量の位相差を加味することで砂堆・反砂堆の発

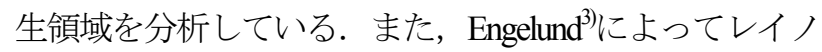
ルズ平均した鉛直 2 次元 Navier-Stokes 方程式 (RANS) を用いた線形安定解析が提案されると，この理論は

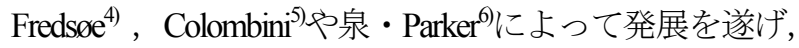
小規模河床波の発生機構や之の遷移過程を物理的に説明 するに至っている.

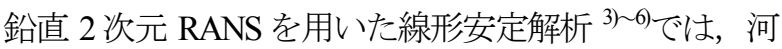
床せん断力と流砂移動の間に位相差の無い平衡流砂量モ デルが採用されている。これらのモデルでは，小規模河 床波の発生は, 鈆直方向の流速を直接計算することで得

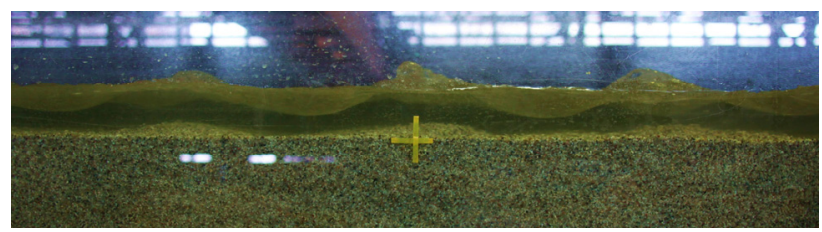

写真-1 実験で観測された反砂堆と水面波

られる，水深平均流速と河床せん断応力間の位相差によ り説明される. しかし，流砂の非平衡性（慣性）によっ て, 河床せん断応力と流砂輸送の応答に位相差が生じ, これが小規模河床波の発生要因になりうることが, Parker ${ }^{7}$ の研究によって示されている. 中川・辻本 ${ }^{8}$ は, 流砂の非平衡性に加え, 流速と河床せん断灾力の位相差 も考慮することにより，小規模河床波の不安定性を説明 している．音田・細田 ${ }^{9}$ は，ポテンシャル流解析を用い て行われた中川・辻本 ${ }^{8}$ の研究を発展させ, 鉛直加速度 を考慮した水深積分モデル（原形ブシネスクモデル）と 非平衡流砂量式を組み合わせることにより，砂堆・反砂 堆の発生・発達過程を数值解析で再現することに成功し ている.このように小規模河床波の発生要因を合理的に モデルに組み込むことにより，鈆直方向の流れを直接計 算せずとも河床波の表現が可能なモデルが提案されてき ている ${ }^{10,11)}$. 


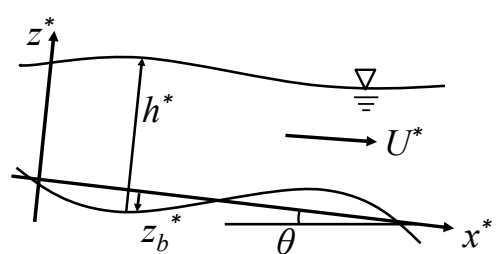

図-1 座標系の説明図

音田・細田の数值計算モデル ${ }^{9}$ は，計算負荷や複雑場 への適用等の面から利点が大きいが，水深積分モデルを 用いた場合は採用する流れ，流砂モデルの組み合わせが 河床波不安定性を決定する. 数值解析ではどちらのモデ ルが河床波不安定性によ゙のような影響を及ぼしているか 分かりにくい，そこで本研究では，音田・細田モデルに 対して線形安定解析を行い，反砂堆に関する既往実験結 果 ${ }^{12,13), 14)}$ と比較するとともに，ブシネスク項や流砂モデ ル (平衡・非平衡) が河床波不安定性や波長へ与える影 響を明らかにする。

\section{2. 基礎式の誘導過程}

本研究では，主目的である(A)ブシネスク方程式 $\times$ 非 平衡流砂量モデルの線形安定解析だけでなく，(B) 浅水 流方程式 $\times$ 非平衡流砂量モデル，(C) ブシネスク方程式 $\times$ 平衡流砂量モデル，(D) 浅水流方程式 $\times$ 平衡流砂量モ デルの線形安定解析も行う，4つのモデルの解析結果を 比較することで，ブシネスク項や流砂モデル（平衡・非 平衡）が及ぼす影響を分析する.

\section{(1) ブシネスク方程式}

ここでは，流体の鉛直加速度に起因する非静水圧分布 を考慮した 1 次元流れの基礎式(ブシネスク方程式) ${ }^{91,15)}$

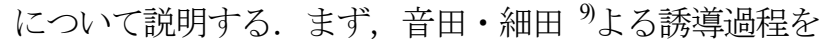
簡単に記載する. 流下方向 $x *$ の流速成分 $u^{*}$ の水深方向 の一様性を仮定すると，次式となる.

$$
u^{*}\left(x^{*}, z^{*}\right)=U^{*}\left(x^{*}\right)
$$

ここで， $u^{*}$ は流速ベクトルの $x^{*}$ 方向成分， $z^{*}$ は水深方向 軸， $U^{*}$ は水深平均流速である。 * は次元量を表す. 式(1) を連続の式，

$$
\frac{\partial u^{*}}{\partial x^{*}}+\frac{\partial w^{*}}{\partial z^{*}}=0
$$

に代入し,$z^{*}$ から自由水面まで積分すると次式を得る。

$$
\begin{gathered}
w^{*}=m A^{*}-B^{*} \\
A^{*}=U^{*} \frac{\partial h^{*}}{\partial x^{*}}, \quad B^{*}=U^{*} \frac{\partial z_{b}^{*}}{\partial x^{*}}, \quad m=\frac{z_{b}^{*}+z^{*}}{h^{*}}
\end{gathered}
$$

ここで， $w^{*}$ は流速ベクトルの $z^{*}$ 方向成分， $h^{*}$ は水深， $z_{b}^{*}$ は下向きを正とした河床高の摂動（図-1）である.
式(1), 式(3)を水深方向の運動方程式

$$
u^{*} \frac{\partial w^{*}}{\partial x^{*}}+w^{*} \frac{\partial w^{*}}{\partial z^{*}}=-g h^{*} \cos \theta-\frac{1}{\rho}\left(\frac{\partial p^{*}}{\partial z^{*}}\right)
$$

に代入し,$z^{*}$ から自由水面まで積分すると以下の圧力分 布式が得られる.

$$
\begin{aligned}
& \frac{p^{*}}{\rho^{*}}=g\left(h^{*}-z_{b}^{*}-z^{*}\right) \cos \theta-U^{*} A^{*} \frac{\partial h^{*}}{\partial x^{*}}\left(\frac{1}{2}-\frac{m^{2}}{2}\right) \\
& +U^{*} A^{*} \frac{\partial z_{b}^{*}}{\partial x^{*}}(1-m)+U^{*} h^{*} \frac{\partial A^{*}}{\partial x^{*}}\left(\frac{1}{2}-\frac{m^{2}}{2}\right) \\
& -U^{*} h^{*} \frac{\partial B^{*}}{\partial x^{*}}(1-m)+A^{* 2}\left(\frac{1}{2}-\frac{m^{2}}{2}\right)-A^{*} B^{*}(1-m)
\end{aligned}
$$

ここで， $p^{*}$ は圧力， $\rho^{*}$ は水の密度， $\theta$ は河床勾配である， また，式(5)を $x^{*}$ 方向の運動方程式に代入し，河床から水 面まで積分すると, 次のような基礎式が得られる.ただ し，式(6)は連続式である。

$$
\frac{\partial\left(U^{*} h^{*}\right)}{\partial x^{*}}=0
$$

$$
\frac{\partial\left(U^{* 2} h^{*}\right)}{\partial x^{*}}+\frac{\partial P^{*}}{\partial x^{*}}-\left(\frac{p^{*}}{\rho^{*}}\right)_{b} \frac{\partial z_{b}^{*}}{\partial x^{*}}=g h^{*} \sin \theta-\frac{\tau_{b x}^{*}}{\rho}
$$

ここで， $\tau_{b x}{ }^{*}$ は河床せん断力，添え字のbは路床における 值を表し， $P^{*}$ は水深積分された圧力である.

$$
P^{*}=\int_{-z_{b}^{*}}^{h^{*}-z_{b}^{*}} \frac{p^{*}}{\rho^{*}} d z^{*}
$$

音田・細田 ${ }^{9}$ は，非回転条件を満足する流速分布形を 求め，その河床近傍流速を用いて河床せん断応力を評価 している.また，局所的な加速・減速効果を考慮して河 床せん断応力を補正している．このため，河床波の不安 定性が，河床せん断応力の補正によって生じているのか, それともブシネスク方程式と非平衡流砂量モデルの組合 わせによって生じているのかが不明確である。本研究で は，この点を明らかにするために，河床せん断応力は水 深平均流速 $U^{*}$ と河床抵抗係数 $C_{f}$ を用いて以下のように 単純に評価する.

$$
\frac{\tau_{b x}^{*}}{\rho^{*}}=C_{f} U^{* 2}
$$

ここでは基本変数に対して以下のような無次元化と線 形化を行う.

$$
\begin{gathered}
x^{*}=h_{0}^{*} x \\
U^{*}=U_{0}^{*} U=U_{0}^{*}\left(1+a U_{1}\right) \\
h^{*}=h_{0}^{*} h=h_{0}^{*}\left(1+a h_{1}\right) \\
z_{b}^{*}=h_{0}^{*} z_{b}=a h_{0}^{*} z_{b 1}
\end{gathered}
$$


ここで，添え字の0は等流状態の值を，添え字の1は摂動 を表している. $a$ は摂動の振幅であり, 線形安定解析で は無限小であると仮定する．式(11)を式(7)，式(8)に代入 し， $O(a)$ について整理すると次式が得られる.

$$
\begin{gathered}
\frac{\partial h_{1}}{\partial x}+\frac{\partial U_{1}}{\partial x}=0 \\
F r^{2} \frac{\partial h_{1}}{\partial x}+2 F r^{2} \frac{\partial U_{1}}{\partial x}+\frac{1}{3} F r^{2} \frac{\partial^{3} h_{1}}{\partial x^{3}}-\frac{1}{2} F r^{2} \frac{\partial^{3} z_{b 1}}{\partial x^{3}} \\
+\left(\frac{\partial h_{1}}{\partial x}-\frac{\partial z_{b 1}}{\partial x}\right)=h_{1} \tan \theta-F r^{2} 2 C_{f} U_{1}
\end{gathered}
$$

$F r$ はフルード数 $\left(F r^{2}=U_{0}^{2} / g h_{0} \cos \theta\right)$ である.

摂動は次のように表されるとする.

$$
\left(U_{1}, h_{1}, z_{b 1}\right)=e^{\Omega t} e^{i(\lambda x-\omega t)}\left(U_{1}, h_{1}, z_{b 1}\right)
$$

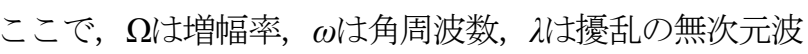
数である. 式(12)と式(13)に式(14)を代入すると次式が得 られる。

$$
\begin{gathered}
i \lambda h_{1}+i \lambda U_{1}=0 \\
\left(F r^{2} i \lambda-\frac{1}{3} F r^{2} i \lambda^{3}+i \lambda-\tan \theta\right) h_{1} \\
+\left(2 F r^{2} i \lambda+2 F r^{2} C_{f}\right) U_{1}+\left(\frac{1}{2} F r^{2} i \lambda^{3}-i \lambda\right) z_{b 1}=0
\end{gathered}
$$

\section{（2） 浅水流方程式}

静水圧を仮定した場合の1次元流れの基礎式（浅水流 方程式）を以下に記述する。 なお，連続式は式(6)と同 じため省略する.

$$
\begin{aligned}
\frac{\partial\left(U^{* 2} h^{*}\right)}{\partial x^{*}}+g h^{*} \cos \theta\left(\frac{\partial h^{*}}{\partial x^{*}}-\frac{\partial z_{b}^{*}}{\partial x^{*}}\right) & \\
& =g h^{*} \sin \theta-\frac{\tau_{b x}^{*}}{\rho}
\end{aligned}
$$

これに，式(11)の無次元化と線形化を導入し， $O(a)$ につ いて整理すると次式が得られる.

$$
\begin{aligned}
& F r^{2} \frac{\partial h_{1}}{\partial x}+2 F r^{2} \frac{\partial U_{1}}{\partial x} \\
& \quad+\left(\frac{\partial h_{1}}{\partial x}-\frac{\partial z_{b 1}}{\partial x}\right)=h_{1} \tan \theta-F r^{2} 2 C_{f} U_{1}
\end{aligned}
$$

式(13)と式(18)を比較すると, 非静水圧分布を考慮した 影響により, 式(13)に水深と河床高の3階微分項が追加さ れていることが分かる.

上述の線形化方程式に式(14)の摂動を与えると，以下 の式が得られる.

$$
\begin{aligned}
& \left(F r^{2} i \lambda+i \lambda-\tan \theta\right) h_{1} \\
& +\left(2 F r^{2} i \lambda+2 F r^{2} C_{f}\right) U_{1}+(-i \lambda) z_{b 1}=0
\end{aligned}
$$

\section{(3) 非平衡流砂モデル}

河床堆積土砂の質量保存則をpick-up rate (= entrainment rate） $E^{*}$ とdeposition rate $D^{*}$ を用いて表すと以下となる

$$
\frac{\partial z_{b}^{*}}{\partial t^{*}}=\frac{1}{1-\lambda_{p}}\left(E^{*}-D^{*}\right)
$$

ここで， $t^{*}$ は時間， $\lambda_{p}$ は空隙率である，中川・辻本 $\left.{ }^{8}\right)$ に ると, 平衡状態において流砂量を平均step length $L_{s}^{*}$ で除 すとentrainment rateになる.

$$
E^{*}=q_{b}^{*} / L_{b}^{*}
$$

$q_{b}^{*}$ は平衡流砂量式を使って求める. Deposition rateについ ては，以下のように求める.

$$
D^{*}=\int_{0}^{\infty} E^{*}\left(x^{*}-s^{*}\right) f_{p}\left(s^{*}\right) d s^{*}
$$

s゙は主流方向軸（x゙とはゼロ点が異なり， pick-up された 地点がゼロ）, $f_{p}$ は step length 確率密度関数であり, 以下 のように指数分布とする.

$$
f_{p}\left(s^{*}\right)=\frac{1}{L_{s}^{*}} \exp \left(-\frac{s^{*}}{L_{s}^{*}}\right)
$$

上述の基礎式に以下の無次元化を導入する.

$$
t^{*}=T_{0}^{*} t, \quad d^{*}=h_{0}^{*} d, \quad s^{*}=d^{*} s, \quad L_{s}^{*}=d^{*} L_{s}
$$

$T_{0}^{*}=\left(1-\lambda_{p}\right) h_{0}^{* 2} / q_{b 0}^{*}, \quad E^{*}=\frac{q_{b 0}^{*}}{h_{0}^{*}} E, \quad q_{b}^{*}=q_{b 0}^{*} q_{b}$

$$
q_{b 0}^{*}=8\left(\tau_{0}-\tau_{c}\right)^{3 / 2} \sqrt{\Delta g d^{* 3}}, \quad \tau_{0}=\frac{C_{f} U_{0}^{* 2}}{\Delta g d^{*}}
$$

ここで, $d$ は粒径, $\tau$ は Shields数, $\tau_{c}$ は限界 Shields 数, $\Delta$ は土粒子の水中比重である. 無次元化された流砂連続式 を以下に示寸。

$$
\begin{gathered}
\frac{\partial z_{b}}{\partial t}=E-D \\
E=\frac{1}{d L_{s}}\left(\frac{\tau-\tau_{c}}{\tau_{0}-\tau_{c}}\right)^{3 / 2} \\
D=\int_{0}^{\infty} E(x-d s) f_{p}(s) d s
\end{gathered}
$$

ここで

$$
f_{p}(s)=\frac{1}{L_{s}} \exp \left(-\frac{s}{L_{s}}\right)
$$

次に, Shields数 $\tau$ を式(11)に従い線形化する.

$$
\tau=\frac{C_{f} U^{* 2}}{\Delta g d^{*}}=\frac{C_{f} U_{0}^{* 2}}{\Delta g d}\left(1+2 a U_{1}^{*}+a^{2} U_{1}^{* 2}\right)
$$


摂動の 2 乗の項は微少と考え無視すると，

$$
\begin{gathered}
\tau=\tau_{0}\left(1+2 a U_{1}^{*}\right) \\
\frac{\tau-\tau_{c}}{\tau_{0}-\tau_{c}}=\frac{\tau_{0}-\tau_{c}}{\tau_{0}-\tau_{c}}+\frac{2 \tau_{0} U_{1}}{\tau_{0}-\tau_{c}}=1+2 a \Theta U_{1} \\
\Theta_{0}=\frac{\tau_{0}}{\tau_{0}-\tau_{c}}
\end{gathered}
$$

式(31)を式(26)に代入し，テイラー展開を用いると以下の 式となる,

$$
E=\frac{1}{d L_{s}}\left(1+2 a \Theta U_{1}\right)^{3 / 2} \approx \frac{1}{d L_{s}}\left(1+3 a \Theta U_{1}\right)
$$

式(27)に式(32)を代入すると，

$$
\begin{aligned}
& D=\frac{1}{d L_{s}} \int_{0}^{\infty}\left[\left(1+\left.3 a \Theta U_{1}\right|_{x=x-d_{g} s}\right) f_{p}(s)\right] d s= \\
& \frac{1}{d L_{s}} \int_{0}^{\infty}\left[f_{p}(s)\right] d s+\frac{1}{d L_{s}} \int_{0}^{\infty}\left[\left.3 a \Theta U_{1}\right|_{x=x-d_{g} s} f_{p}(s)\right] d s
\end{aligned}
$$

ここで, $f_{\mathrm{p}}(s)$ は 0 から無限大まで積分すると, 確率密度 関数の定義から 1 となる. 従って,

$$
D=\frac{1}{d L_{s}}+\frac{1}{d L_{s}} \int_{0}^{\infty}\left[\left.3 a \Theta u_{1}\right|_{x=x-d_{g} s} f_{p}(s)\right] d s
$$

式(32), 式(34)を式(25)に代入すると, 以下の線形化方程 式が得られる.

$$
\frac{\partial z_{b 1}}{\partial t}=3 \Theta U_{1}-\frac{3 \Theta}{d L_{s}} \int_{0}^{\infty}\left[\left.U_{1}\right|_{x=x-d_{g} s} f_{p}(s)\right] d s
$$

上述の線形化方程式に式(14)の擾乱を与える. なお式

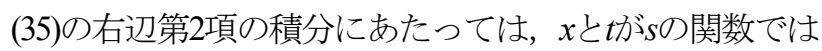
ないことに注意して以下の関係を利用する.

$$
\begin{aligned}
& \left.\int_{0}^{\infty} U_{1}\right|_{x=x-d s} f_{p}(s) d s \\
& =\frac{e^{\Omega t}}{L_{s}} U_{1} \int_{0}^{\infty} e^{i(\lambda x-\omega t)-i \lambda d s} \exp \left(-\frac{s}{L_{s}}\right) d s \\
& =\frac{e^{\Omega t} e^{i(\lambda x-\omega t)}}{L_{s}} U_{1} \int_{0}^{\infty} \exp (-i \lambda d s) \exp \left(-\frac{s}{L_{s}}\right) d s
\end{aligned}
$$

最終的に式(35)は以下の式で表される.

$$
(\Omega-i \omega) z_{b 1}-3 \Theta\left(\frac{\lambda}{1+\left(d \lambda L_{s}\right)^{2}}\left(i+d \lambda L_{s}\right)\right) U_{1}=0
$$

\section{(4) 平衡流砂モデル}

河床堆積土砂の質量保存則を単位幅流砂量 $q_{b}{ }^{*}$ を用い て表すと以下となる．なお，単位幅流砂量は式(24)に示 すMeyer-Peter and Müllerの式から求める.

$$
\frac{\partial z_{b}^{*}}{\partial t^{*}}=\frac{1}{1-\lambda_{p}} \frac{\partial q_{b}^{*}}{\partial x^{*}}
$$

次に式(24)の無次元化を導入する.

$$
\frac{\partial z_{b}}{\partial t}=\frac{\partial q_{b}}{\partial x}
$$

上述の基礎式に式(11)の摂動を与え， $O(a)$ について整 理すると, 次式が得られる.

$$
\frac{\partial z_{b 1}}{\partial t}=3 \Theta \frac{\partial U_{1}}{\partial x}
$$

ここで式(14)の擾乱を与えると次式が得られる.

$$
(\Omega-i \omega) z_{b 1}-3 \Theta i \lambda U=0
$$

\section{(5) 線形安定解析}

線形化された連続式，運動方程式，流砂連続式を行列 式で表す.

$$
\left(\begin{array}{lll}
a_{11} & a_{12} & a_{13} \\
a_{21} & a_{22} & a_{23} \\
a_{31} & a_{32} & a_{33}
\end{array}\right)\left(\begin{array}{c}
U_{1} \\
h_{1} \\
z_{b 1}
\end{array}\right)=0
$$

式(42)の可解条件は, 左辺の係数行列の絶対值が 0 とな ることである. 線形安定解析では増幅率の正負を調べる ために, この条件から増幅率の方程式を求め, 増幅率が 正であれば，与えた擾乱は成長する（河床波発生）。ま た，有限の正の増幅率ピークを持てば，そのときの波数 が卓越波数になる.

$a_{11} \sim a_{33}$ は採用するモデルの組合わせによって異なる. 例えば，(A)ブシネスク方程式×非平衡流砂量モデルの場 合，式(15)，式(16)，式(37)の組合わせとなり，(B)浅水流 方程式 $\times$ 非平衡流砂量モデルの場合は式(15), 式(19), 式 (37)の組合わせ，(C)ブシネスク方程式 $\times$ 平衡流砂量モデ ルの場合は式(15), 式(16), 式(41)の組合わせ，(D)浅水流 方程式 $\times$ 平衡流砂量モデルの場合は式(15), 式(19), 式 (41)の組合わせになる.

例として，(A)ブシネスク方程式×非平衡流砂量モデル $の a_{11} \sim a_{33}$ を以下に示寸.

$$
\begin{aligned}
& a_{11}=i \lambda \\
& a_{12}=i \lambda \\
& a_{13}=0 \\
& a_{21}=2 F r^{2} i \lambda+2 F r^{2} C_{f} \\
& a_{22}=F r^{2} i \lambda-\frac{1}{3} F r^{2} i \lambda^{3}+i \lambda-\tan \theta \\
& a_{23}=\frac{1}{2} F r^{2} i \lambda^{3}-i \lambda \\
& a_{31}=-3 \Theta \frac{\lambda\left(\lambda d L_{s}+i\right)}{1+\left(\lambda d L_{s}\right)^{2}} \\
& a_{32}=0 \\
& a_{33}=\Omega-i \omega
\end{aligned}
$$




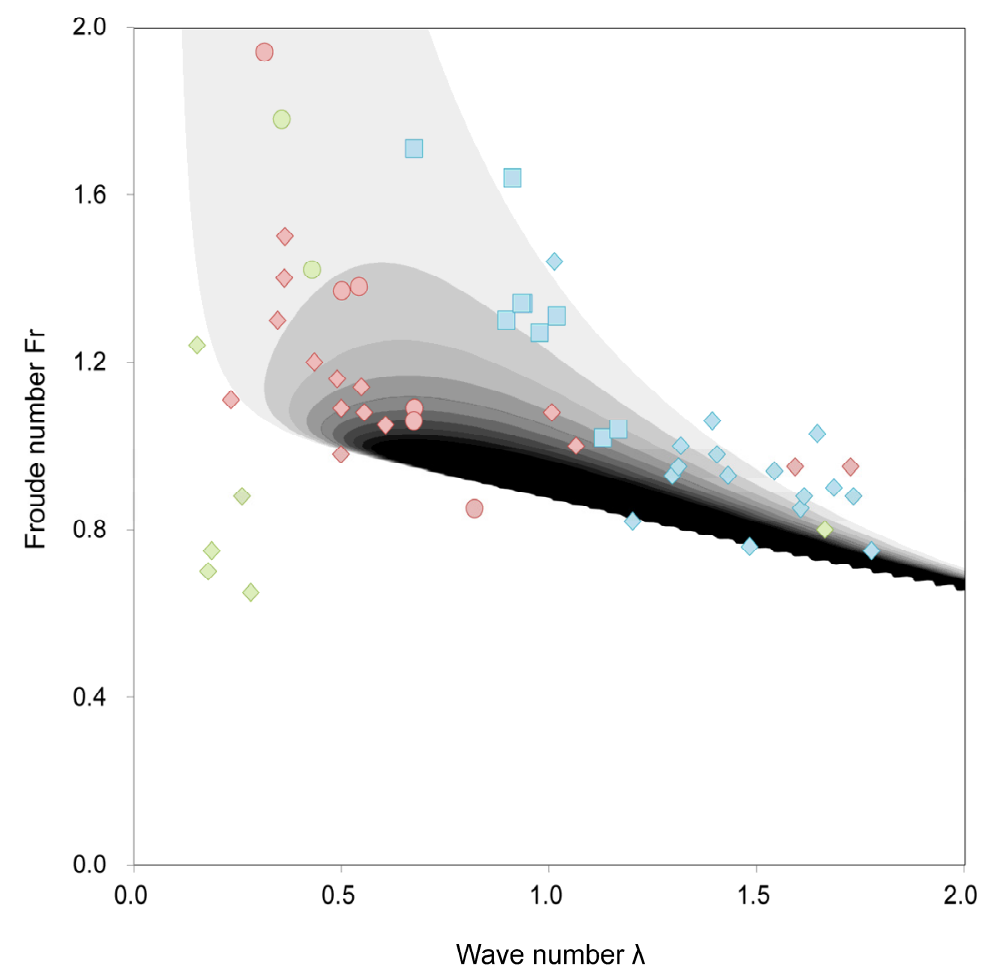

図-2 成長率のコンター図と既往実験結果 ※コンター図は原形ブシネスク方程式と非平衡流砂量式の組合わせによる線形安定解析結果

表-1 井上らの実験条件 ${ }^{12}$

\begin{tabular}{|c|c|c|c|c|c|c|c|c|}
\hline & $\begin{array}{c}\text { 水路幅 } \\
(\mathrm{m})\end{array}$ & $\begin{array}{c}\text { 粒径 } \\
(\mathrm{mm})\end{array}$ & 勾配 & $\begin{array}{c}\text { 流量 } \\
(\ell / \mathrm{s})\end{array}$ & $\begin{array}{c}\text { 平均水深 } \\
(\mathrm{m})\end{array}$ & フルード数 & $\begin{array}{c}\text { 無次元 } \\
\text { 掃流力 }\end{array}$ & $\begin{array}{c}\text { 反砂堆 } \\
\text { 発生有無 }\end{array}$ \\
\hline Run1 & 0.5 & 1.42 & 0.0080 & 15.2 & 0.045 & 1.02 & 0.154 & 発生 \\
\hline Run9 & 0.5 & 5.00 & 0.0320 & 21.7 & 0.040 & 1.73 & 0.155 & 非発生 \\
\hline
\end{tabular}

\section{3. 結果と考察}

\section{(1) 既往研究との比較}

(A)ブシネスク方程式 $\times$ 非平衡流砂量モデルによる線 形安定解析結果と田中 ${ }^{12)}$, 福岡ら ${ }^{13)}$, 井上ら ${ }^{14)}$ が行った 反砂堆の実験結果との比較を図-2に示す．増幅率 $\Omega>0$ の 領域が不安定領域であり, 擾乱が発達する領域である. 擾乱が発達しない増幅率 $\Omega<00$ 領域は図が見づらくなる ため描画していない. なお平均step length $L_{s}$ は一般的によ く用いられる粒径の100倍とし, 河床抵抗係数は対象と した実験から逆算したC の年間值とした（今回用いた実 験において $C$ は $10^{-2} 〜 20^{-2}$ の範囲にあった）。

図-2によると，本解析結果は概ね既往実験で流下反砂 堆（青シンボル）, 遡上反砂堆（赤シンボル）が発生し た領域と一致している. 不安定領域から外れている緑の 菱形群は, 反砂堆ではなくChutes \& Poolsである. このこ とから, 本解析モデルの適用範囲は反砂堆に留まる.

泉・Parker ののRANSを用いた線形安定解析結果をみる と, フルード数が 0.8 以下で波数 0.3 付近に砂堆に相当す る不安定性が存在しているが, 本研究の線形安定解析で
はこれが存在しない.ブシネスク方程式と非平衡流砂量 モデルの組合わせは, 反砂堆を発生させる位相差を表せ るが，砂堆を発生させるのに必要な位相差は表せないと 考えられる. 砂堆の位相差を評価するためには，中川・ 辻本 ${ }^{8)}$, 音田・細田 ${ }^{9}$, Luchini and Charru ${ }^{16)}$ が指摘している ように，局所的な加速・減速効果を考慮した底面せん断 応力評価式を用いる必要がある. 底面せん断応力評価式 を用いた場合の線形安定解析については後述する.

井上らの実験 ${ }^{12)}$ において, 反砂堆は Shields 数が約 0.15 以上の領域で発生しやすいが，フルード数が高くなると 発生しにくいことが報告されている，そこで，ほぼ同じ Shields 数でフルード数の異なる Run 1 と Run 9（表-1）を 用いて線形安定解析を行った. 図-3 に増幅率と波数の 解析結果を示す. これによると, フルード数が小さい Run 1 では正の増幅率の值が大きい領域が波数 0.4 付近に ある. 一方，フルード数が大きい Run 9 では，増幅率が 正の領域があるものの，その值は Run 1 に比べ非常に小 さい.このことは，高フルード数時に反砂堆が発生しに くくなった既往実験結果と同じ傾向を示しており，モデ ルの妥当性がうかがえる. 


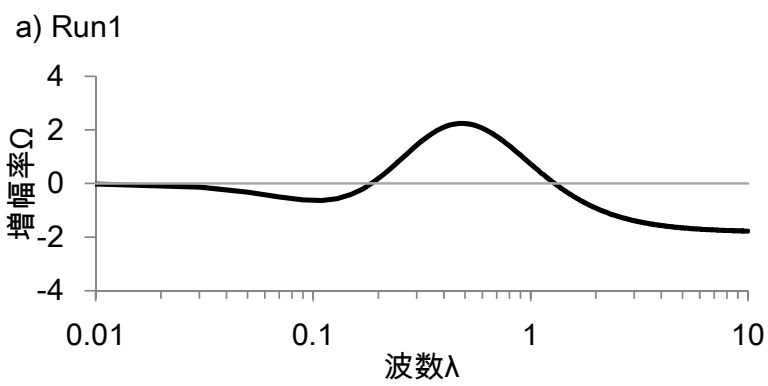

b) Run 9

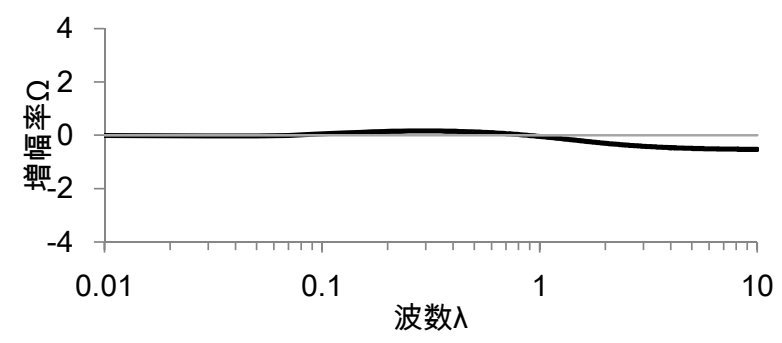

図-3 増幅率と波数の関係

※原形ブシネスク方程式 $\times$ 非平衡流砂量式の組合わせ

a) $\mathrm{Cf}=20^{-2}$ の場合

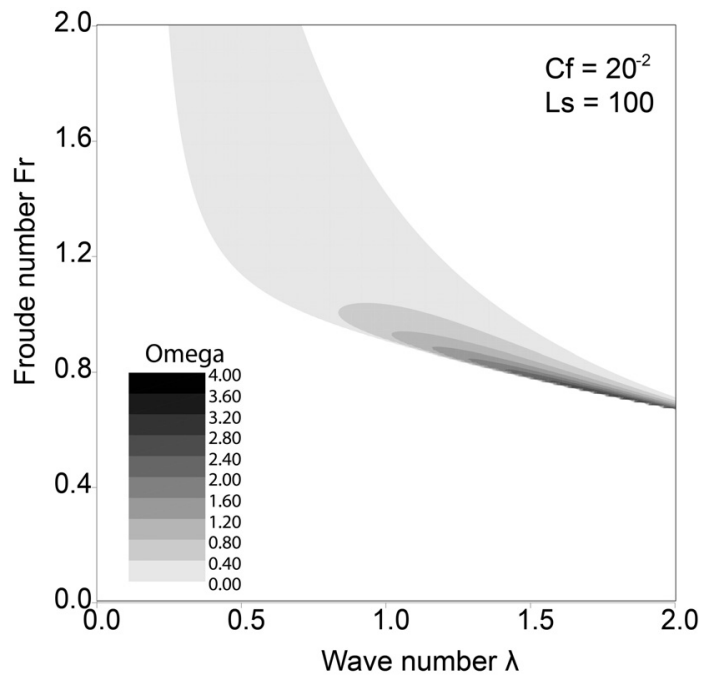

b) $\mathrm{Cf}=10^{-2}$ の場合

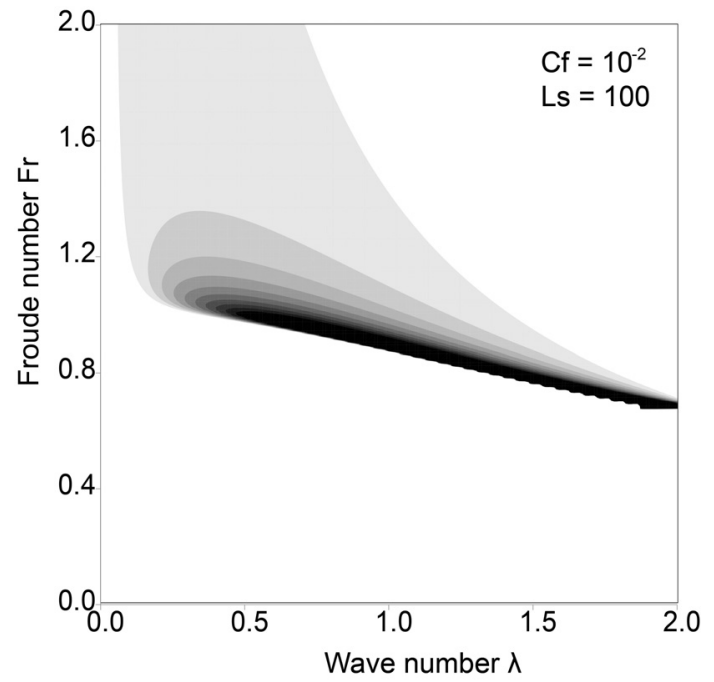

図-4 河床抵抗係数が不安定性に及ぼす影響

\section{2) パラメータの違いによる不安定性}

河床抵抗係数 $C_{f}$ 亡平均Step length $L_{s}$ が河床波の不安定性 に及ぼす影響を分析した。図-4をみると，河床抵抗係数 が大きくなると，波数が小さい領域の増幅率が正になり， 不安定領域が増加する。 また, 図一5をみると, 平均Step lengthが小さくなると, 波数が小さい領域の増幅率が正 になり，不安定領域が増加する。このことから，抵抗係 数や平均step lengthが大きいほど（小さいほど），波数が 小さい領域で反砂堆不安定領域が大きくなる（小さくな る）傾向がうかがえる.

上述の傾向は，鉛直二次元RANSモデルを用いた泉・

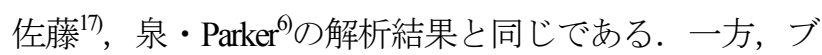
シネスク方程式と非平衡流砂量モデルの組合わせたモデ ルにおいて，これらのパラメータは波数が大きい領域に おける不安定領域にそれほじ影響を与えておらず，不安 定領域全体が小さくなる泉・佐藤 ${ }^{17)}$, 泉・Parker'の結果 とは若干傾向が異なっている，この違いについては，実 験結果なども踏まえて，さらなる分析が必要である.

a) Ls=10dの場合

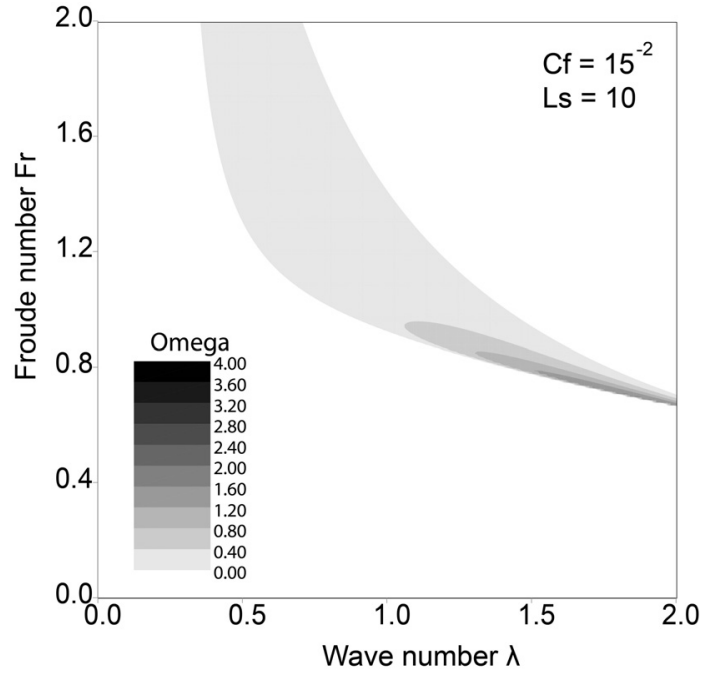

b) Ls=300dの場合

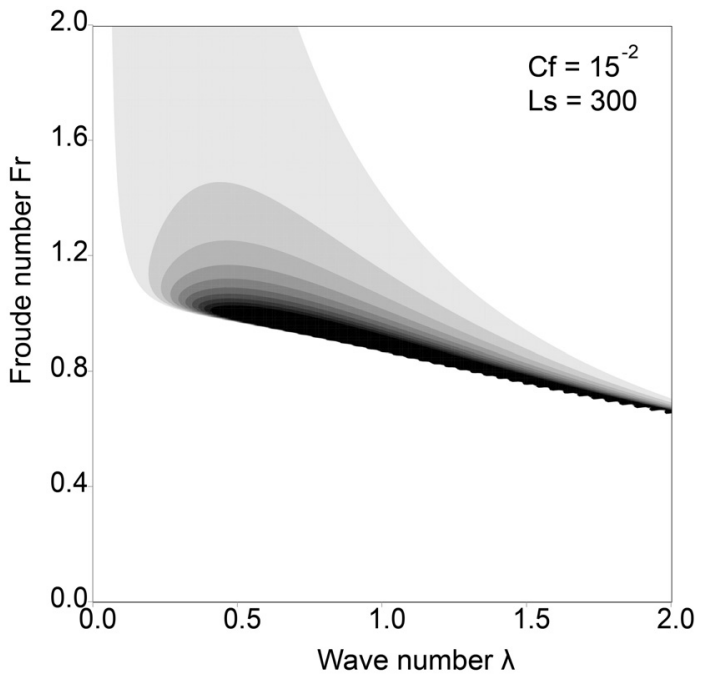

図-5 平均 Step length が不安定性に及ぼす影響 
a) 原形ブシネスク方程式十非平衡流砂モデル

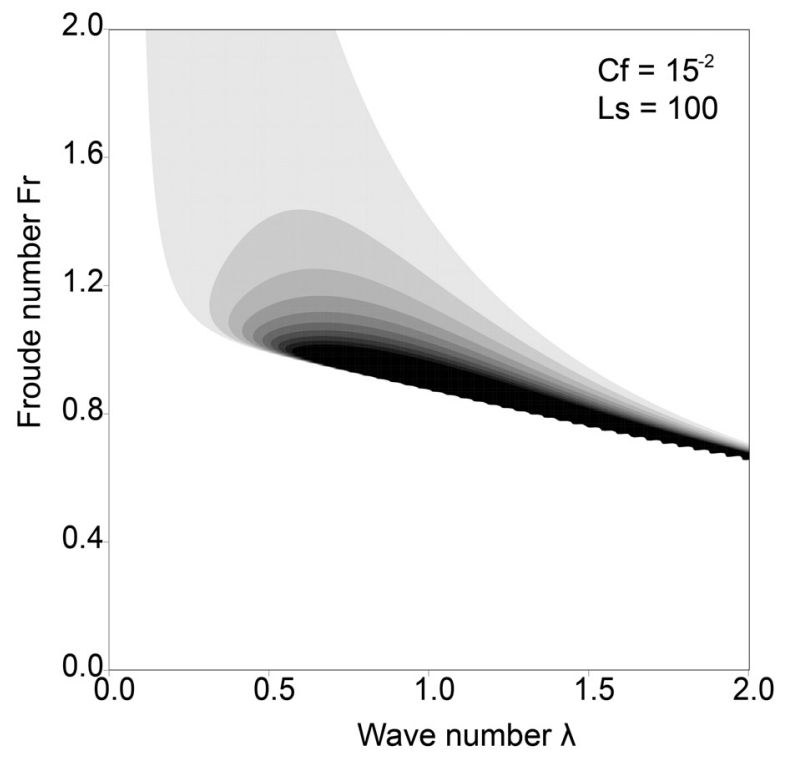

b) 浅水流方程式十非平衡流砂モデル

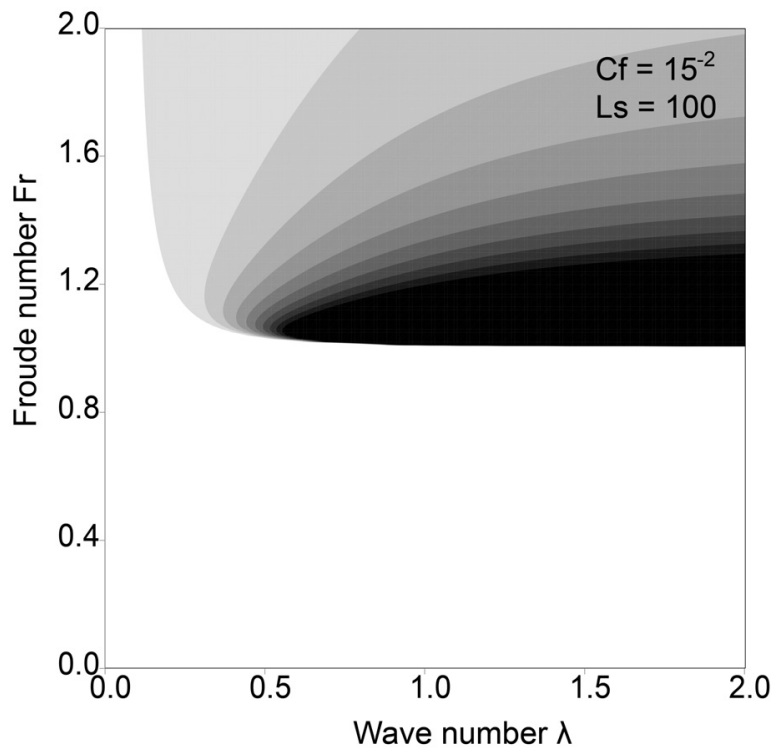

c) 原形ブシネスク方程式十平衡流砂モデル

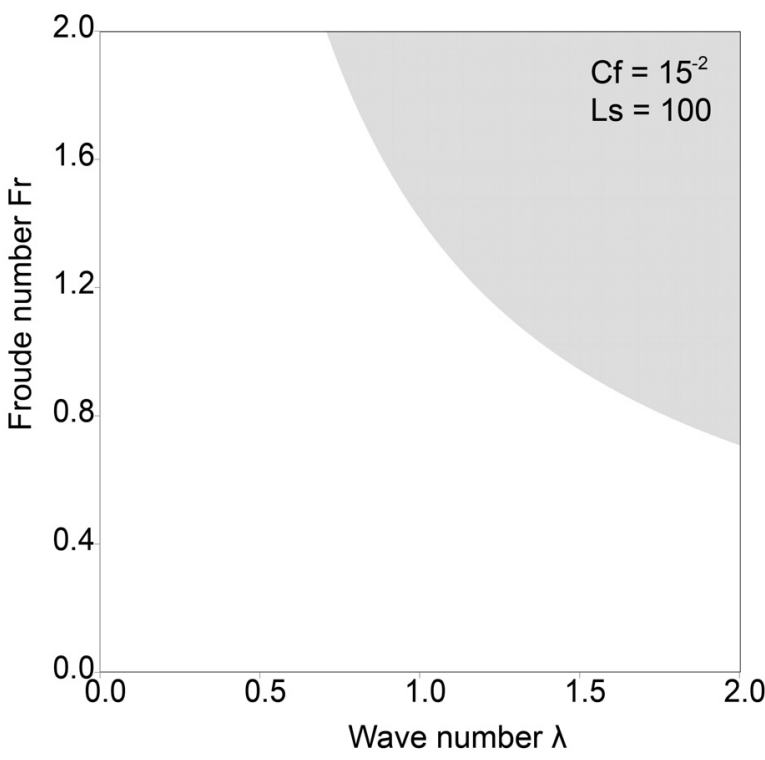

d) 浅水流方程式十平衡流砂モデル

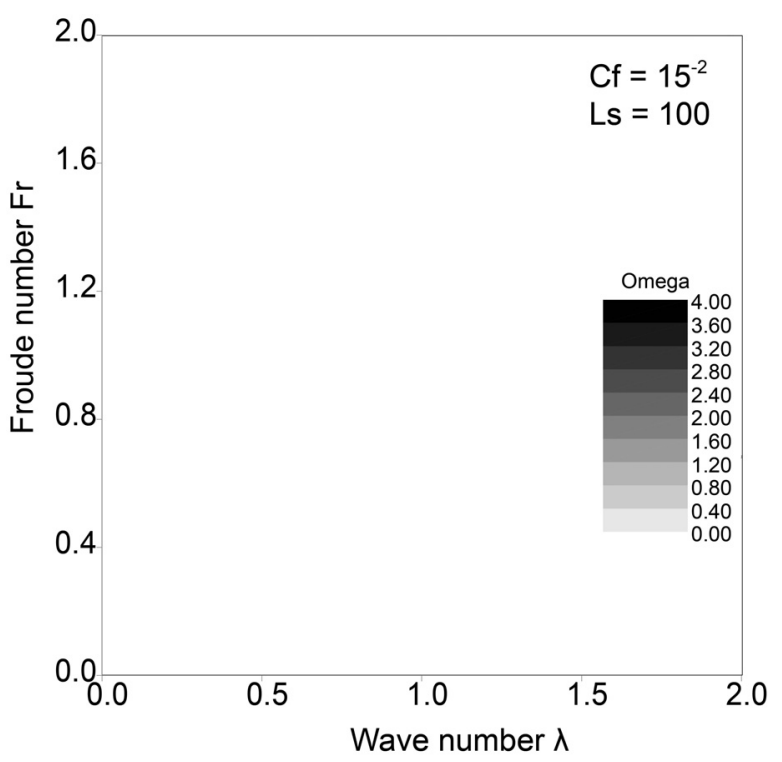

図-6 モデルの違いによる不安定領域の違い

\section{（3）モデルの組合わせの違いによる不安定性}

図-6は，a) 原形ブシネスク式十非平衡流砂モデル（図 -2 と同様），b) 浅水流方程式十非平衡流砂モデル，c) 原 形ブシネスク式十平衡流砂モデル，d) 浅水流方程式十平 衡流砂モデルの 4つのモデルを用いて線形安定解析を行 った結果である.これによると，a)のモデルはピークを 持った不安定性があり，有限波長を持った波が発達する 可能性がある，b)のモデルは，不安定性はあるが波数の ピークが無く，波数が大きいほど増幅率が大きいため, 波長が決定されない. 数值計算に適用した場合, 初期に 発達する波は，採用した格子サイズで解像可能な最も波 長の小さい波となる可能性が高い. c)のモデルは, 眓か らは分かりにくいが，非常に緩やかなピークを持ってい る.ただし, その波数は図-2 に示した反砂堆の実験結
果と比較して大きすぎる. d)のモデルは一次元河床変動 計算でよく使われる組み合せであるが不安定領域が現れ ず，反砂堆は発生しない.

c)のモデルにピークがあることから，ブシネスク項は 有限波長の河床波を誘起する効果を持っている．ただし， その波数は反砂堆としては大きく増幅率も弱い. これに， 小さい波数に対しての不安定性を有するb)の流砂非平衡 性が合わさることにより，ブシネスク項の持つ不安定領 域が小さい波数の領域にシフトするとともに，増幅率が 強化されたと解釈できる，これは，流砂の非平衡性，ブ シネスクモデルの効果はそれぞれ単独では反砂堆の発生 を説明するには不十分であるが，組み合わせることによ り反砂堆の発生を説明しうることを示唆している. 
a) $\Gamma=0, \Delta=0$ の場合

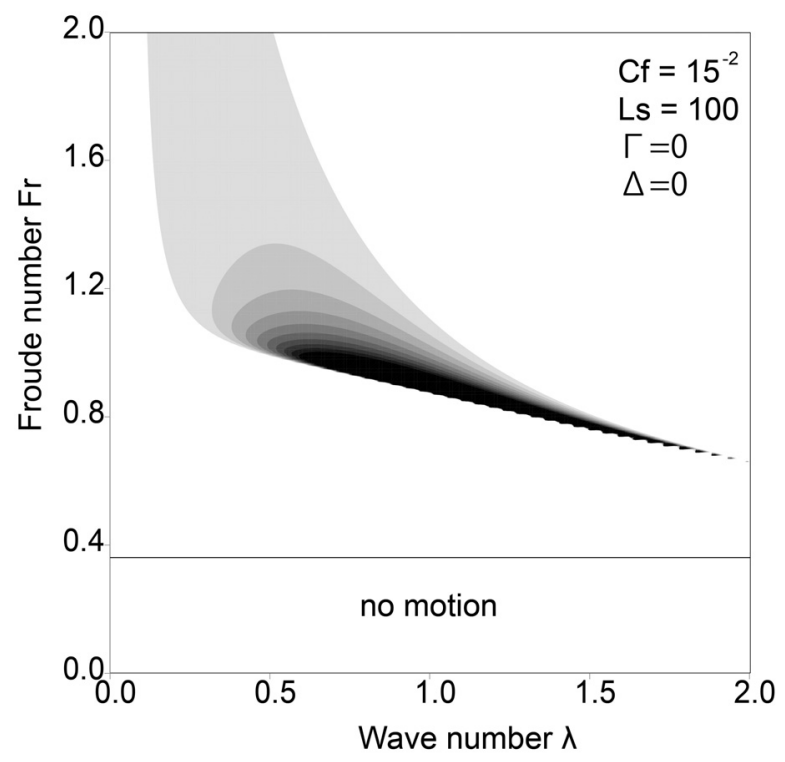

c) $\Gamma=1, \Delta=2$ の場合

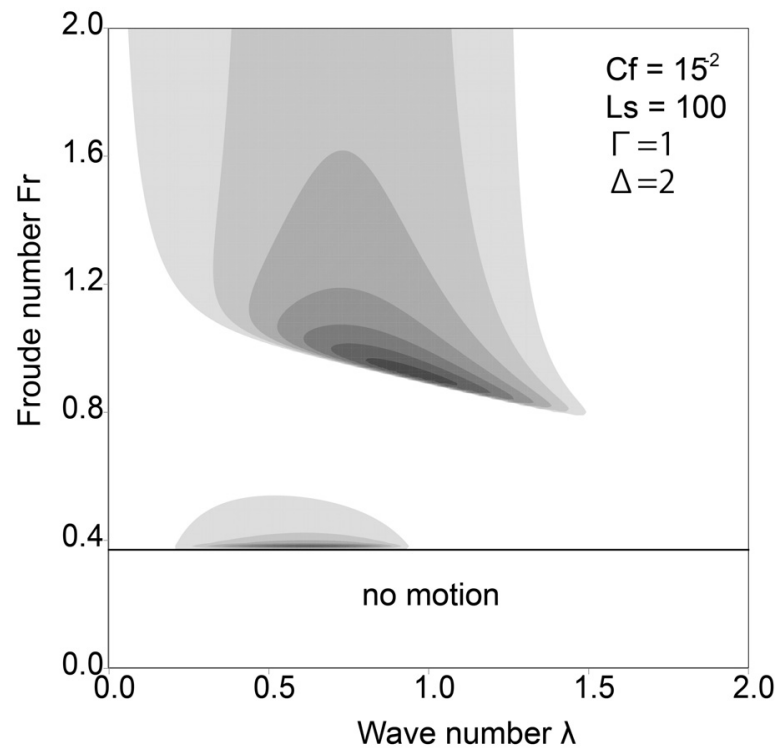

b) $\Gamma=2, \Delta=1$ の場合

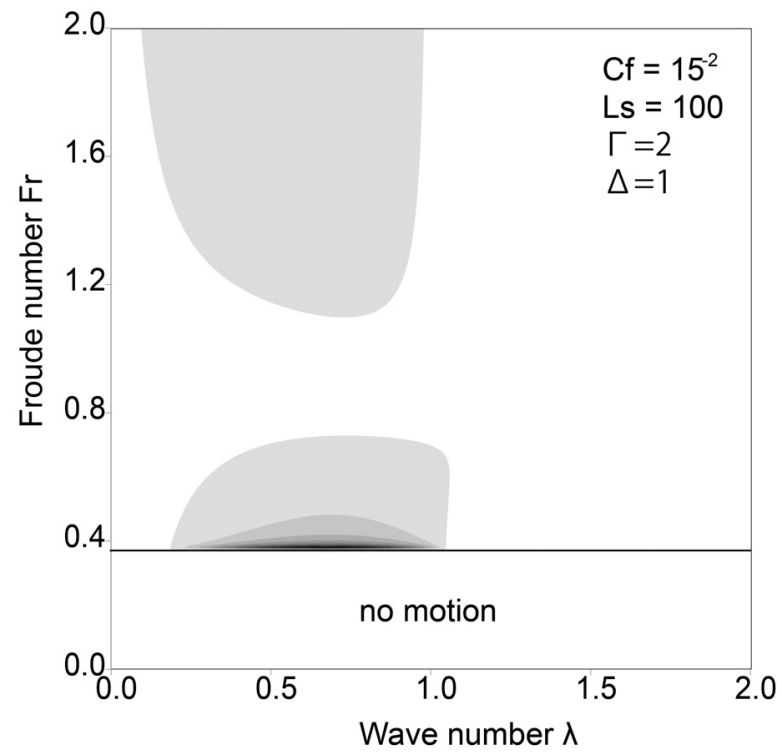

d) $\Gamma=3, \Delta=0$ の場合

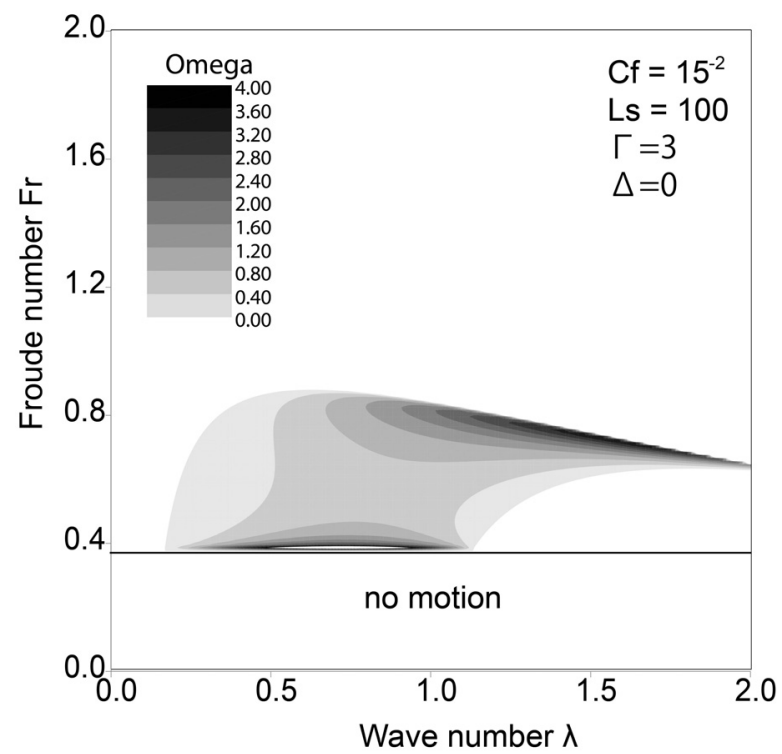

図-7 原形ブシネスク方程式十非平衡流砂モデル十底面せん断応力評価式 ${ }^{18)}$ の不安定領域

\section{(4) 底面せん断応力の評価}

音田・細田の数值計算モデル9゙たいて，底面せん断 応力は細田ら ${ }^{18)}$ によって提案された評価式によって計算 される，細田らは，まず路床からある程度離れた領域の 流速分布形の変化を，流れの非回転条件を用いて以下の ように求め ${ }^{18)}$,

$$
\begin{aligned}
& u_{b}^{*}=U^{*}+\frac{U^{*}}{3}\left(\frac{\partial h^{*}}{\partial x^{*}}\right)^{2}-U^{*} \frac{\partial h^{*}}{\partial x^{*}} \frac{\partial z_{b}^{0}}{\partial \widetilde{x}^{*}} \\
& -\frac{U^{*} h^{*}}{6} \frac{\partial^{2} h^{*}}{\partial x^{* 2}}+\frac{U^{*} h^{*}}{2} \frac{\partial^{2} z_{b}^{*}}{\partial x^{* 2}}
\end{aligned}
$$

さらに, Nakagawa \& Tsujimoto $^{19)}$ が提案した底面せん断応 力の評価式に, 路床変動の空間微分を追加した以下の式 を提案している ${ }^{18)}$.

$$
\frac{\tau_{b x}^{*}}{\rho}=C_{f} u_{b}^{* 2}\left(1-\Gamma \frac{\partial h^{*}}{\partial x^{*}}-\Delta \frac{\partial z_{b}^{*}}{\partial x^{*}}\right)
$$

$\Gamma, \Delta$ は定数であり, 細田らは実験を通じた経験的な值 として $\Gamma=2, \Delta=1$ を提案している. 式(44)はブシネスク 方程式の考えの範疇にあり，ブシネスク方程式を用いる 場合はセットで用いるのが理に適っている. 一方, 式 (45)の括弧内は流れの水深積分モデルで表しきれない境 界層の発達に起因する位相差を加味するための付加項で ある。

図-7 は式(44), 式(45)を線形化し，ブシネスク方程式 $\times$ 非平衡流砂量モデルの組み合わせに導入した場合の線形 あ安定解析結果を示している. (a)は $\Gamma=0, \Delta=0$ とし付加 項を考慮していない場合であり，非回転条件から求めた 
路床近傍の流速とそれに応じた底面せん断応力が考慮さ れている.これとシンプルな式(9)を用いた図-6(a)とを比 較すると, 不安定領域が若干小さくなるものの傾向は変 わらない（砂堆の不安定性が生じていない）ことが分か る. 既往研究により, 非平衡流砂量式は反砂堆を発生さ れる位相差を表現できるが，砂堆を発生させる位相差を 表せないことが確認されている わ. 今回，ブシネスク方 程式およびブシネスク方程式から派生する路床近傍の流 速分布式も反砂堆を発生される位相差は表せるが砂堆を 発生させる位相差を表せないことが確認できた.

次に(b)の $\Gamma=2, \Delta=1$ とし付加項を考慮した場合をみる と, フルード数1以下の領域に砂堆の不安定性が現れる 結果となっており, 砂堆と反砂堆の両方を表すためには, 式(45)で表される付加項が必要と言える.ただし， $\Gamma, \Delta$ を加えると反砂堆領域（特に，波数が1以上に多く分布 する流下反砂堆）の再現性が低下する（図-2参照）。ま た，図-7に示したように， $， \Delta$ 組合せによって不安定 領域が大きく変化するため，例えば，流下反砂堆である 三角波を表現したい場合 $I=0, \Delta=0$ とするなど，対象と する現象に応じて適切な值を採用する必要がある.

\section{4. まとめ}

音田・細田9)が提案する原形ブシネスクモデルと非平 衡流砂量式の組み合わせで線形安定解析を行い，既往の 反砂堆実験結果と良好な整合性を得た。これは，音田・ 細田 ${ }^{9}$ が示した水深積分モデルを用いた反砂堆の数值計 算の妥当性に対して理論的な側面から説明を与えたもの といえる.

(A)ブシネスク方程式 $\times$ 非平衡流砂量モデルの線形安 定解析, (B) 浅水流方程式 $\times$ 非平衡流砂量モデル, (C) ブシネスク方程式 $\times$ 平衡流砂量モデル，(D) 浅水流方程 式 $\times$ 平衡流砂量モデルの4つの組合わせに対し線形安定 解析を行った結果, ブシネスク項や流砂の非平衡性は, それぞれ単独では反砂堆の波長を説明するには不十分で あるが，2つの組み合わせにより波長が決定されること が確認された。

(A)ブシネスク方程式 $\times$ 非平衡流砂量モデルに，細田 らが提案する底面せん断応力の評価式を加え線形安定解 析を行った.まず, 細田らの評価式の前半部分, 路床近 傍流速分布だけを考慮して解析したが，砂堆不安定性は 再現できなかった．砂堆の不安定性を評価するためには， 境界層の発達に起因する位相差を表す付加項を考慮する 必要がある。

今後は，ブシネスク方程式と非平衡流砂量モデルの組 合せを平面2次元へ拡張し，急流河川で発生する3次元的 な反砂堆と水面波を再現しうるかを検討するとともに, 数值計算を行うことで非線形領域におけるモデルの挙動
を明らかにする予定である。

謝辞 : 本研究にあたつては，北開水工コンサルタントの 長谷川和義先生, River Link $の$ 旭一岳博士, 寒地土木研究 所の川村里実研究員にご助言を頂きました.ここに記し て謝意を表します。

\section{参考文献}

1)Kennedy, J. F. : The mechanics of dunes and antidunes in erodible-bed channels, J. Fluid Mech., Vol. 16, pp.521-544, 1963.

2)Hayashi, T. : Formation of dunes and antidunes in open channels, Journal of Hydraulic Division, Proc. of ASCE, Vol. 96, No.HY2, pp. 357-366, 1970.

3)Engelund, F.: Instability of erodible beds, J. Fluid Mech., Vol. 42, pp. 225244, 1970.

4)Fredsøe, J.: On the development of dunes in erodible channel, J. Fluid Mech., Vol. 64,pp.1- 16,1974.

5)Colombini, M.: Revisiting the linear theory of sand dune formation, J. Fluid Mech., Vol. 502,pp.1-16, 2004.

6)泉典洋, Gary Parker: 平坦床-反砂堆遷移過程の分岐特性, 水工学 論文集, Vol. 53, pp.733-738, 2009.

7)Parker, G. ; Sediment inertia as cause of river antidunes, J. Hydraul. Div. ASCE 101,211-221, 1975.

8)中川博次, 辻本哲郎: 砂碩の運動に伴う移動床砂面の擾乱発生 過程，土木学会論文報告集，No.291,pp.53-62, 1979.

9)音田慎一郎, 細田 尚: 水深積分モデルによる小規模河床波の発 生・発達過程と流れの抵抗則の数值解析, 水工学論文集, Vol. 48,pp.973-978, 2004.

10)Vesipa, R., Camporeale, C. and Ridolfi, L. : A shallow-water theory of river bedforms in supercritical conditions, Physics of Fluids, Vol.24, 094104, 2012.

11)内田龍彦・福岡捷二 : 浅水流の仮定を用いない水深積分モ デルによる種々な小規模河床形態の統一的解析法の構築, 土 木学会論文集 B1（水工学）, Vol. 69, No. 4, pp.I_1135-I_1140, 2013.

12)田中祐一郎 : Antidune に関する実験的研究, 京大防災研年報第 13 号 B, pp.271-284, 1970..

13)福岡捷二, 奥津一夫, 山坂昌成 : 急勾配移動床流れにおける河 床波の形状,伝播特性, 土木学会論文集, Vol.323,pp.77-89, 1982.

14)井上卓也, 長谷川和義, 渡部靖憲, 船木淳悟: 三次元的な反砂堆 上の水面波に関する実験的研究, 土木学会論文集 A2(応用力 学),Vol.71,No.2,I_739-I_746,2015.

15)細田尚, 余越正一郎: 三次元波状路床上の流れに関する解析, 広島大学工学部研究報告, Vol.32, No. 1,pp.47-51, 1983.

16)Luchini, $P$ and F. Charu : The phase lead of shear stress in shallow-water flow over a perturbed bottom, J. Fluid Mech., Vol. 665, pp. 516-539, 2010. 17)泉 典洋・佐藤博重 : 掃流砂の非平衡性を考慮した河床デュ ーンの線形安定解析, 北海道河川財団 研究所紀要(XVIII), 2007. 
18)細田 尚，村本嘉雄，宮本雅章 : 水深積分モデルによる波状 路床上の流れの底面せん断応力解析, 土木学会論文集, No.558/II-38, pp.81-89, 1997.
19) Nakagawa, H. and Tsujimoto, T. : Sand bed instability due to bed load motion, Proc.ASCE, Vol.106, HY 12, pp.2029-2051, 1980.

(2016. 6. 24 受付)

\title{
ANTIDUNE INSTABILITY ASSOCIATED WITH A DEPTH-AVERAGED MODEL WITH AN ENTRAINMENT-BASED MODEL
}

\author{
Takuya INOUE, Toshiki IWASAKI and Shinichiro ONDA
}

Dynamics of river bedforms which is an interfacial instability phenomenon between turbulent open channel flow and movable bed significantly affect the flow structures and sediment transport dynamics in rivers, so that this have been an classical and important research topic in the field of river engineering. Here, we perform a linear stability analysis for several combinations of flow and sediment transport submodels, specifically, a shallow flow model and a Boussinesq type depth-integrate model for hydrodynamic model, and an equilibrium and a non-equilibrium bedload transport model for sediment mass conservation model. We then investigate how the submodels adopted determine the linear stability and the wavelength of river bedforms. The results show that the combination of the Boussinesq model and the non-equilibrium bedload transport model can explain the antidune instability and its finite wavelength observed in several published experiments, whereas, use of each submodel alone is insufficient to explain the finite wavelength of antidunes. 